\title{
The Determinant of Quality ICT-based Teaching and Learning
}

\author{
Slameto \\ Magister of Educational Management \\ Universitas Kristen Satya Wacana Salatiga, Indonesia \\ slameto@staff.uksw.edu
}

\begin{abstract}
The Open / Distance Learning was deemed feasible to produce an undergraduate education equivalent to regular on-campus graduate program. For the development of on-line learning, managers needed to select the variables determining the success; Factors that contributed to the sustainability needs to be explored and promoted; while this variable had not been found. This study tried to find the determinants of the quality of ICTbased teaching and learning. This study was quantitative methods, conducted based on the assessment of alumni. Data were collected through a self-rating scale consisting of 32 items that had been proven its validity and reliability; Data analysis used descriptive analysis and stepwise multiple regression models. The quality of teaching and learning were at the high level and moderate. There were three models of the determinants of the quality of teaching and learning namely: student admission, student admission and budgeting, and student admission, budgeting and lecturer of qualifications. The findings was very important for the management and supervision of distance education in order to improve the quality of teaching and learning; improving the system of admissions selection, increasing the amount of financial aid in order to support the education, and increasing the lecturers' professionalism.
\end{abstract}

Keywords-budgeting, lecturer qualifications, Open/ distance learning (ODL), quality of teaching and learning, student admission.

\section{INTRODUCTION}

As the world is moving rapidly into digital media and information, the role of ICT in education is becoming more and more important and this importance will continue to grow and develop in the 21st century [1]. The Bachelor of Education Inservice Teachers Program (BEITP) that is conducted by lecturers through Open/ Distance Learning (ODL) is deemed feasible to produce an undergraduate education equivalent to regular on-campus graduate program [2]. BEITP program is acceleration program to increase academic teacher qualification become S-1. Since 2009, in Indonesia, it has been conducted by 55 various universities. To increase the academic qualification of primary school teachers, through S-1 Primary Teacher Educational Program, using open/distance learning system, known as ICT-based BEITP.
Teaching staff and administrators had a strong desire to integrate ICT into teaching-learning processes $[3 ; 4]$. The innovations that ICT has brought to teaching \& learning process include: E-learning... etc. However, the presence of all these factors increased the chance of excellent integration of ICT in teaching-learning process. The potential of ICTs to improve teaching and learning is explored; it is argued that the three-way relationships between learner, teacher and materials lie at the heart of the education quality [5]. There are 6 dimensions and 20 critical success factors for e-learning systems in developing countries. Findings illustrate the importance of curriculum design for learning performance. The awareness of technology, motivation, and changing learners' behavior are prerequisites for successful e-learning implementations [6]. Further the program is expected to realize the implementation of the teacher education system [7] those are efficient, effective, and accountable as well as offering wider educational services access without sacrificing the quality. For the development of on-line learning, managers need to select the variables determining the success; Factors that contribute to the sustainability needs to be explored and promoted [8]; while this variable has not been found.

Research questions are formulated: 1) How is the quality of teaching and learning of BEITP for teachers through open/distance learning; 2) What comorbid factors that will determine the quality teaching and learning of BEITP graduate. Comorbid factors are limited to: 1) curriculum, 2) lecture material, 3) assessment system, 4) the qualifications of lecturers, 5) device lecture 6), the independence of the fund, and 7) the recruitment of students. Among those factors, it is unaccounted which one became the determinants of quality of teaching and learning; whereas the very important determinant for quality improvement of education management O/DL.

\section{LITERATURE REVIEW}

A system approach looks both inward and outward, focusing on relationships and patterns of interaction between subsystems and their environments within the organization. In this o/dl context, terms such as input, process, output, control and feedback are frequently used for describing, analyzing, and evaluating our institutions [9]. In o/dl program, a component input is limited to: 1) the recruitment of students/ admission, 2) qualification of lecturers, 3) curriculum, 4) teaching material, 5) assessment system, 6) learning tools and 7) budgeting and will affect the quality of the process that is the quality of lectures. 
New admission system is the system used to conduct the recruitment process for new students include: registration, examination process, selection process, new student's announcement, and new student's registration [10]. The purpose of the organization is to support the efforts of BEITP acceleration of academic qualification for in-service teacher; hence the new admissions process is done through credible selection procedures in accordance with the requirements of the academic and administrative requirements that are applied in each university organizers.

To organize BEITP, the providers are required to have qualified faculty as remain specified in the policy and legislation. Lecturer serves as custodian of the course with the basic tasks of teaching and is responsible for the entire implementation of the lecture and task to develop learning tools such as course descriptions, syllabus, lecture events unit, preparation of assignments or examination questions, as well as developing teaching materials [11].

Curriculum is a set of plans and arrangements regarding the purpose, content, teaching materials and methods used to guide the organization of learning activities to achieve education goals [12]. The curriculum of the Bachelor Degree is same with a Bachelor Degree BEITP regular, and should stick to Competency Standards. The curriculum used in BEITP is applicable curriculum at each high college organizers. Competency Standards covering the four core competencies, namely: pedagogical, personal competence, social competence, and professional competence. Self-study material is the substance of learning developed in the form of printed materials, audio, and audio-visual equipment that can be used for student self-learning process.

As a demand of the curriculum, teaching method should be able to keep the quality of achieving the Competency Standards. The learning process in BEITP is implemented through the integration of lectures/learning and face-to-face learning or college-mediated and independent learning activities. In face-to-face activities in campus, the development system of teaching materials given entirely to the lecturers at the university course organizers, while the self-directed learning system using the Self-Study Materials. Self-study material designs specifically to be studied independently by students [13]. The form of instructional materials (modules) as the main teaching material could be printed or could become non-printed media such as audio/video media, computer/ Internet, radio and television) as a support material or a combination of both.

Assessment of learning outcomes will be given value to the process and also the results of student learning, both in face-toface lectures and/or mediated and independent learning; Assessment of learning outcomes is conducted on the process and outcomes of student learning, both in face-to-face lectures and/or mediated and independent learning [14]. Learning outcomes is carried out by given assessment in accordance with the provisions applicable in each college, such as: assessment of the course activities, mid-semester exams, and final exams on the end of semester.
Learning tools is arranged using learning activities systematically by the teacher in the learning process such as: lesson plan, syllabus, work sheets, and others. "The device is a learning material, tools, media, instructions and guidelines to be used in the learning process" a series of learning tools must be prepared to face the teacher in the classroom, the learning can include: lesson plan, student books, teacher handbooks, student activity sheets, and achievement test [15]. Economic factor is a significant impact on student achievement, this suggests that the higher of students' economic independence level, the higher its success; it happens for the cost of tuition and learning facilities, as well as the necessities of life and learning requires costs which are adequate by the students.

The process of learning is a form of communication that is the subject of communication between students and educators, students and faculty. The communication contains transform and transfer of knowledge, skills or attitudes and values of the communicators (teachers, lecturers) to the communicant (subject learners, students) in accordance with its intended purpose [16]. The learning process is a learning activity that is done by integrating the system face-to-face lectures and/or mediated and self-learning systems. To face lectures are scheduled process and the direct interaction between faculty and students in achieving objectives/ competencies. Mediated lecture is scheduled interaction process between faculty and students in achieving sublime goal/competency through the use of various types of media and technology. Self-regulated learning is the process of student interaction with learning resources, which is done by using self-learning materials, either with or without the helping of assistance tutorial. Tutorial assistance is a form of academic study that is directly related to teaching materials, and can be carried out face-to-face or mediated.

Quality of teaching in university can be defined as one that engages the student in an in-depth and comprehensive approach to the subject matter, that is, in an active, durable, and critical construction of knowledge integrated with his or her previous knowledge and put to action [17]. However, the measure of quality teaching and learning needs to focus on the dimensional factors that directly influence the delivery process of instructional design and the course outcomes. There are eight principles that underscore effective teaching: (1) enhancing students' general capabilities and work-related skills (2) using student experience as a learning resource (3) encouraging active and co-operative learning (4) promoting responsibility in learning (5) engaging with feelings, values and motives (the affective domain) as well as with intellectual development (6) fostering open, flexible, reflexive and outcome-based assessment (7) evaluating teaching and learning to encourage reflective teaching, and (8) developing organization-wide strategies to establish congruence of policies to enhance physical and material learning environment [18].

The study that students perceptions of quality learning included experiences that helps them to link theory with the real world, assignments relevant to real work place, discussions leading to new perspectives of thinking, and curriculum that took account of the students' group 
experiences and imparted added value to students. The emergence of three major teaching strategies which are highly rated by students in higher education: delivery strategy and techniques in the classroom; feedback to students in the classroom and in assignments; and relationship with students in the classroom [19].

This study aims to describe the quality of ICT-based lecture BEITP program based on an assessment of alumni; after the study is trying to find the determinants of the quality of ICTbased lecture program among the variables that can be done as effective treatments in order to improve the quality of this program.

Significance of the Study - Knowing the level of quality of teaching and learning of ICT-based ODL program will be very useful for managers as a feedback in taking decision sustainability. Theoretically, the study finds a model determinant of the quality of lectures for this program so that the policy/ practical can be done to improve the quality of lectures effectively.

\section{METHOD}

This study was conducted based on the assessment of the alumni who had Attended BEITP. The population of the study was alumni of Open/ Distance Learning Primary Teacher Training Program UKSW Salatiga scattered in 5 regions namely in Kebumen, Grobogan, District Pati, Kudus and Batang regency. The samples were randomly selected, taken from one districts namely Batang regency of 48 people.

Based on the formulation of the problem posed, it appeared that this research was inferential quantitative research. The quantitative research revealed inferential relationship between two or more variables that could explained the symptoms, which examined the effect of variables $\mathrm{X}_{1}$ (curriculum), $\mathrm{X}_{2}$ (lecture material), $\quad X_{3}$ (assessment system) $\quad X_{4} \quad$ (the qualifications of lecturers), $\mathrm{X}_{5}$ (device lecture), $\mathrm{X}_{6}$ (the independence of the fund) and $X_{7}$ (the recruitment of students) to $\mathrm{Y}$ (quality of teaching and learning); and then found the determinant variable of seven independent variables in question. The time of this study was the 2nd half of 2014/2015.

Statistical Hypothesis - In ordinal order, the variable of quality of teaching and learning, there was one dominant level among four categories: low, medium, high and very high. Among the 7 independent variables, there were positively significant determinant on the quality of lectures ICT-based ODL program. In other words, the regression coefficient predictor determinant $\left(b_{1}\right)$ was significantly positive. Statistical hypothesis proposed were:

$\mathrm{H}_{0}: \mathrm{b}_{1}=0 \quad$ (There is no determinant influence on quality of teaching and learning of BEITP for teachers through open/distance learning)

$\mathrm{H}_{1}: \mathrm{b}_{1} \neq 0$ (There is a determinant influence on quality of teaching and learning of BEITP for teachers through open/distance learning)

The effects on individual or multiple was discovered by looking at the value of $b$ in the determinant variable.
Furthermore, the significance of value $\mathrm{b}$ will be tested by t-test. $\mathrm{T}$ significance was seen in its value. If $\mathrm{b}$ was positive, and $\mathrm{t}$ was significant at an error rate of less than 0.05, the hypothesis $\mathrm{H}_{1}$ would be accepted.

Instruments and Data Analysis Techniques - The data of this study was quantitative data in the form of numbers; Ordinal data was data that was expressed in forms of categories and ranked. Ordinal scale used was the ranking scale (Likert Scale) that consists of statements and answers with low, medium, high and very high corresponding to measurement purposes. Data were collected through a self-rating scale consisting of 32 items that had been proven its validity and reliability; Score validity 0.199 to 0,827 , with a reliability index Cronbach's alpha $=0.93$.

Data of values of variables were analyzed by using frequency distribution and linear regression (double) with Stepwise Model. The collected instruments items were set the calculation of factor analysis. Furthermore, the researcher creates the model of relationship (causal models). The patterns of the independent variables influence (determinant) on the dependent variable were tested by F test at the 0.05 levels. This calculation was carried out with SPSS version 20.

In the testing concept model, the determinant coefficient from the independent variable to the dependent variable was calculated. The calculation result of the determination coefficient from seven independent variables in this study on the dependent variable was adjusted by $\mathrm{R}^{2}$ coefficient. If the significance $\mathrm{r}$ was less than or equal to 0.05 , this model was declared significant, as $\mathrm{X}_{1-7}$ (selected) influenced $\mathrm{Y}$, as much as adjusted $\mathrm{R}^{2}$ coefficient.

\section{DATA ANALYSIS}

After a descriptive analysis of data collected for each variable were the results as follows.

TABLE I. RESULTS OF A DESCRIPTIVE ANALYSIS OF ALL VARIABLES STUDIED

\begin{tabular}{lccccc}
\hline & Mean & Median & $\begin{array}{c}\text { Std. } \\
\text { Dev }\end{array}$ & Min. & Max. \\
\hline$X_{1}$ Curriculum & $\mathbf{3 , 0 3 1 3}$ & $\mathbf{3 , 0 0 0 0}$ & $\mathbf{0 , 5 0 7 0 1}$ & $\mathbf{2 , 5 0}$ & $\mathbf{4 , 0 0}$ \\
X $_{2}$ teaching materials & $\mathbf{2 , 6 5 6 3}$ & $\mathbf{3 , 0 0 0 0}$ & $\mathbf{0 , 6 0 1 5 8}$ & $\mathbf{2 , 0 0}$ & $\mathbf{4 , 0 0}$ \\
X $_{3}$ Assessment & $\mathbf{2 , 9 4 3 8}$ & $\mathbf{2 , 8 0 0 0}$ & $\mathbf{0 , 3 3 0 1 4}$ & $\mathbf{2 , 4 0}$ & $\mathbf{3 , 8 0}$ \\
X $_{4}$ Lecturer of qualificatin & $\mathbf{3 , 2 5 0 0}$ & $\mathbf{3 , 0 0 0 0}$ & $\mathbf{0 , 4 3 9 9 4}$ & $\mathbf{3 , 0 0}$ & $\mathbf{4 , 0 0}$ \\
X $_{5}$ Learning tools & $\mathbf{3 , 1 8 7 5}$ & $\mathbf{3 , 0 0 0 0}$ & $\mathbf{0 , 3 9 6 5 6}$ & $\mathbf{3 , 0 0}$ & $\mathbf{4 , 0 0}$ \\
X $_{6}$ Budgeting & $\mathbf{2 , 4 0 6 3}$ & $\mathbf{2 , 0 0 0 0}$ & $\mathbf{0 , 6 6 5 2 4}$ & $\mathbf{1 , 0 0}$ & $\mathbf{4 , 0 0}$ \\
X $_{7}$ Student Admission & $\mathbf{2 , 9 4 7 9}$ & $\mathbf{3 , 0 0 0 0}$ & $\mathbf{0 , 5 1 5 7 7}$ & $\mathbf{2 , 3 3}$ & $\mathbf{4 , 0 0}$ \\
Y Quality of TL & $\mathbf{3 , 0 6 2 5}$ & $\mathbf{3 , 0 4 5 5}$ & $\mathbf{0 , 2 6 8 7 3}$ & $\mathbf{2 , 7 3}$ & $\mathbf{3 , 6 4}$ \\
\hline
\end{tabular}

Based on the analysis presented in Table 1 above, the average value (mean) of variables: Y (Quality of Teaching and Learning), $\mathrm{X}_{3}$ (Assessment), $\mathrm{X}_{4}$ (Lecturer of qualifications), $\mathrm{X}_{5}$ (Learning tools), and $\mathrm{X}_{6}$ (Budgeting) larger than the figure the median, this means that the spread of each variable question had a tendency toward higher; While the average value of variables: $\mathrm{X}_{2}$ (teaching materials), $\mathrm{X}_{7}$ (Student Admission) was less than then median, this means deployment of each variable in question had a lower tendency. Furthermore, to determine the Quality of Teaching-Learning Process graduated Bachelor Degree conducted a descriptive analysis of the results is at the 
level of very high $(8.40 \%)$, high $(46.80 \%)$, moderate $(43.80 \%)$. No one was at the level of the low.

After testing the normality and homogeneity met, then it was performed by stepwise multiple regression analysis models the effect of 7 variable $X$ to the Quality of Teaching and Learning (Y), the result of hypothesis testing was obtained as the following in table 2.

\begin{tabular}{|c|c|c|c|c|}
\hline & \multicolumn{2}{|c|}{ TABLE II. } & \multicolumn{2}{|c|}{ MODEL SUMMARY } \\
\hline Model & $\mathbf{R}$ & $\begin{array}{c}\text { R } \\
\text { Square }\end{array}$ & $\begin{array}{l}\text { Adjusted } \\
\text { R Square }\end{array}$ & $\begin{array}{c}\text { Std. Error } \\
\text { Of the } \\
\text { Estimate }\end{array}$ \\
\hline 1 & $0,701^{a}$ & 0,492 & $\mathbf{0 , 4 7 5}$ & $\mathbf{0 , 1 9 4 7 3}$ \\
\hline 2 & $0,845^{b}$ & 0,713 & 0,693 & 0,14880 \\
\hline 3 & $0,902^{\mathrm{c}}$ & 0,813 & 0,793 & 0,12219 \\
\hline \multicolumn{5}{|c|}{ Predictors: (Constant), $\mathrm{X}_{7}$ Student Admission } \\
\hline \multicolumn{5}{|c|}{ Predictors: (Constant), $\mathrm{X}_{7}$ Student Admission, $\mathrm{X}_{6}$ Budgeting } \\
\hline \multicolumn{5}{|c|}{ Predictors: (Constant), $\mathrm{X}_{7}$ Student Admission, $\mathrm{X}_{6}$ Budgeting, } \\
\hline \multicolumn{5}{|c|}{ Dependent Variable: Quality of Teaching-Learning Process } \\
\hline
\end{tabular}

bellow, it summarized that $\mathrm{X}_{7}$ (Student Admission) be the determinant of the Quality of Teaching-Learning Process (Y) of 47,50\% (Model 1), which when followed by $\mathrm{X}_{6}$ (Budgeting), its effect on the $\mathrm{Y}$ (Quality of Teaching and Learning) amounted to $69.30 \%$ (model 2), especially in $\mathrm{X}_{7}$ (Student Admission) and X6 (Budgeting), followed by $\mathrm{X}_{4}$ (Lecturer of qualifications), the influence the third variable to Y (Quality of Teaching and Learning) held in distance learning program increased to $79.30 \%$ (model 3).

This means that only less than $21 \%$ were influenced by the other variables that were not observed in this model. Other variables, namely: $\mathrm{X}_{1}$ (Curriculum), $\mathrm{X}_{2}$ (teaching materials) $\mathrm{X}_{3}$ (Assessment), and $X_{5}$ (Learning tools) supported the data that it did not affect the Y (Quality of Teaching and Learning).

Furthermore, to determine whether the findings of the above three models significantly, can be examined in Table 3 the results of the ANOVA analysis as below.

TABLE III. THE RESULTS OF THE ANALYSIS ANOVAD

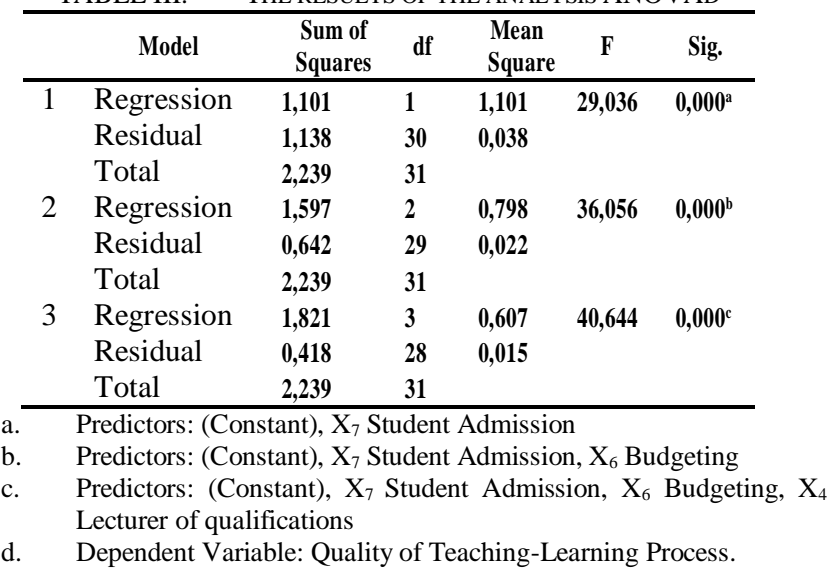

Based on the results of stepwise multiple regression analysis models as presented in Table 4 above, obtained $\mathrm{F}=$ 29.036 with a significance level of 0.00 (Model 1), $\mathrm{F}=36.056$ with a significance level of 0.00 (model 2), and $F=40.644$ with a significance level of 0.00 (Model 3); This means that the three variables in: Model $1 \mathrm{X}_{7}$ (student admission), and model 2 plus $\mathrm{X}_{6}$ (budgeting), and model 3 along with $\mathrm{X}_{4}$ (the lecturer of qualifications) become determinants of the $\mathrm{Y}$ (quality of teaching-learning) were supported by data to meet the level of significance; that mean the hypothesis $\mathrm{H}_{1}$ be accepted. Based on the results of the analysis as presented above, it resulted that quality of teaching-learning process (Y) was not affected by: $\mathrm{X}_{1}$ (curriculum), $\mathrm{X}_{2}$ (teaching materials), $\mathrm{X}_{3}$ (assessment) and $\mathrm{X}_{5}$ (learning tools) used in distance learning.

\section{DISCUSSIONS}

The success of the implementation of ICT was not dependent on the availability or the absence of one individual factor. These factors were interrelated but determined through a dynamic process involving a set of interrelated factors. It was suggested that ongoing professional development must be provided for teachers to model the new pedagogies and tools for learning with the aim of enhancing the teaching-learning process $[20 ; 21]$.

To determine the quality of teaching-learning process in open/distance learning graduated bachelor degree conducted a descriptive analysis of the results are at the level of very high $(8.40 \%)$, high $(46.80 \%)$, moderate $(43.80 \%)$. Based on the results of the analysis there were 3 models of the determinant of the quality of teaching-learning process: student admission, budgeting and lecturer of qualifications; the influence of the third variable to the quality of teaching-learning process was $79.30 \%$. There was a set of in total 65 determinants that were examined in the context of TMLS evaluation. Thereby, we collected data for the systematic TMLS model development, providing a foundation as well as hints for the systematic identification of additional variables [22].

To be an effective teacher (higher Quality of TeachingLearning) did not only involve having a deep content knowledge, but also organizational, management and communication skills, being able to organize instructions, and providing relevant assessment and fair evaluations [23; 24; 25]. In addition, an effective teacher is responsible to create a warm classroom climate, to promote enthusiasm, motivation and an interactive teacher-student relationship. Also, it implies to be caring and understandable, and above all, to enhance learning [23].

The key factors that could contribute to an effective and worthwhile learning and teaching environment [26; 27; 28; 29], that it is the interaction of the following five key factors that provide a foundation for a good teaching: 1) teacher knowledge, enthusiasm and responsibility for learning, 2) classroom activities that encourage learning, 3) assessment activities that encourage learning through experience, 4) effective feedback that establishes the learning processes in the classroom, and 5) effective interaction between the teacher and the students, creating an environment that respects, encourages and stimulates learning through experience [30].

\section{CONCLUSION}

To determine the quality of teaching-learning process in open/distance learning graduated bachelor degree, it conducts descriptive analysis where the results are at the level of very high $(8.40 \%)$, high $(46.80 \%)$, moderate (43.80). Based on the 
results of the analysis there are three models of the determinants of the quality of teaching and learning: 1) student admission (influential at 47.50\%), 2) student admission and budgeting (influential at 69.30\%), and 3) student admission, budgeting and lecturer of qualifications (influential at 79.30\%). The findings of the three variables determinant Quality of Teaching and Learning in the Bachelor of Education In-Service Teachers ICT-based program is very important for management and supervision of distance education in order to improve the quality of teaching and learning: a) the first priority should be improving the system by tightening admissions selection, only qualified students that should be accepted, b) increasing the amount of financial aid in order to support education, and c) increasing the lecturers' professionalism for: (1) enhancing students' general capabilities and work-related skills (2) using student experience as a learning resource (3) encouraging active and co-operative learning (4) promoting responsibility in learning (5) engaging with feelings, values and motives as well as with intellectual development (6) fostering open, flexible, reflexive and outcome-based assessment (7) evaluating teaching and learning to encourage reflective teaching, and (8) developing organization-wide strategies to establish congruence of policies to enhance physical and material learning environment.

\section{REFERENCES}

[1] Umaru, R. I. (2014). ICT and Education of the Child in the 21 st Century. Journal of Resourcefulness and Distinction, 9(1).

[2] Slameto, (2014). The Performance of The Bachelor Education InService Teachers Programme ICT-based BEITP Bachelor Graduated and Its Determinants. http://docplayer.net/17590037.

[3] Ali, G., Haolader, F. A., \& Muhammad, K. (2013). The role of ICT to make teaching-learning effective in higher institutions of learning in Uganda.International Journal of Innovative Research in Science, Engineering and Technology, 2(8), 4061-4073;

[4] Ali MQ, Nargis N, Yasmeen R, Iqba Z. (2015). ICT Use for Effective Teaching-Learning Process in Secondary Schools in Punjab Province. Asian Journal of Social Sciences \& Humanities Vol. 2015 Aug; 4:3.

[5] Ali Barrett A, Ali S, Clegg J, Hinostroza JE, Lowe J, Nikel J, Novelli M, Oduro G, Pillay M, Tikly L, Yu G. (2007). Initiatives to improve the quality of teaching and learning: A review of recent literature. Bristol, England: Edqual. 2007 Oct.

[6] Bhuasiri W, Xaymoungkhoun O, Zo H, Rho JJ, Ciganek AP. (2012). Critical success factors for e-learning in developing countries: A comparative analysis between ICT experts and faculty. Computers \& Education. 2012 Feb 29; 58 (2): 843-55.

[7] Hsieh FJ, Lin PJ, Chao G, Wang TY. (2012). Policy and practice of mathematics teacher education in Taiwan. Retrieved February. 2009;20

[8] Dickinson, J. (1996). Factors affecting goal completion of adult basic education students in the northeast kingdom of Vermont. Unpublished Master's Thesis, Lyndon State College, Lyndonville, Vermont.[on-line] Available: http://www. na. d. ca/fulltext/ thesis/thesis1. Htm;

[9] Du Mont, Rosemary Ruhig, and Ohio Learning Network. (2002). "Distance Learning: A Systems View an Assessment and Review of the Literature."

[10] Gaengler, P. and Falk-Nilsson, E. (2002), "Introduction to theme 1: cognition and the dental student", European Journal of Dental Education, Vol. 6 No. 3, p. 7.

[11] Okiki, O. C., and O. O. Adewumi. (2015). E-Learning Design, Learner Support and Development Project in the Nigeria Educational System.

[12] Perraton, Hilary, Charlotte Creed, and Bernadette Robinson. (2002). Teacher Education Guidelines: Using Open and Distance Learning. Technology, Curriculum, Cost, Evaluation.
[13] Bacigalupo, R., et al. (2001). "Studying health informatics from a distance: issues, problems and experiences." Health Informatics Journal 7.3-4 (2001): 138-145.

[14] Coats, M., and Anne Stevenson. (2006). "Towards outcomes-based assessment: An unfinished story of triangulation and transformation."

[15] Liaw, Shu-Sheng, Hsiu-Mei Huang, and Gwo-Dong Chen. (2007) "Surveying instructor and learner attitudes toward e-learning." Computers \& Education 49.4 1066-1080.

[16] Kember, David. (2001). "Beliefs about knowledge and the process of teaching and learning as a factor in adjusting to study in higher education." Studies in Higher Education 26.2; 205-221.

[17] Entwistle, N. and Ramsden. (1987). Understanding Student Learning. London: Croon Helm.

[18] Pennington, G. and M. O'Neil. (1994). Enhancing the quality of teaching and learning in higher education. Quality Assurance in Education 2(3): 13-18

[19] Hill, Y., Lomas, L., and MacGregor, J. (2003). Students' Perceptions of quality in higher education. Quality Assurance in Education, Vol.11, No. $1,15-20$

[20] Mojgan Afshari, et all. (2009). "Factors Affecting Teachers' Use of Information and Communication Technology." Online Submission 2.1 (2009): 77-104.

[21] Piccoli G, Ahmad R, Ives B. (2001). Web-based virtual learning environments: A research framework and a preliminary assessment of effectiveness in basic IT skills training. MIS quarterly. 2001 Dec 1:40126.

[22] Bitzer P, Janson A. (2014) Towards a Holistic Understanding of Technology Mediated Learning Services-A State-of-the-Art Analysis. European Conference on Information Systems (ECIS), Tel Aviv, Israel $2014 \mathrm{Jul} 24$

[23] Moreno Rubio, C. (2009). Effective Teachers - Professional and Personal Skills, en Ensayos, Revista de la Facultad de Educación de Albacete, $\mathrm{N}^{\circ}$ 24, 2009. http://www.uclm.es/ ab/educacion/ ensayos

[24] Tleuzhanova, G. K., \& Madenyatova, A. M. (2014). The Professional Competence Of Teachers: Which Skills And Knowledge Contribute To A Teacher's Effectiveness?. Education and Science Without Borders, 5(9), 146.

[25] Chrisastum, G. J., John, M. G., \& Glenn, J. A. (2014). International Journal of Advanced Multidisciplinary Research (IJAMR).

[26] Teeranusoun, T. (2013). Students evaluation on factors affecting effective teaching in science field of Assumption University. Scholar, 5(2), 61.

[27] Dargahi, H., Hamouzadeh, P., Sadeghifar, J., Raadabadi, M., Roshani, M., Salimi, M., \& Soltanzadeh, P. (2011). Criteria assessment of a expect teacher for effective teaching. Journal of Payavard Salamat, 4(3), 91-98.

[28] Aregbeyen, O. (2010). Students perceptions of effective teaching and effective lecturer characteristics at the University of Ibadan, Nigeria. Pakistan Journal of Social Sciences, 7(2), 62-69.

[29] Awuor, O. S., \& Chemutai, F. (2015). The Role Of Teachers' Training In Effective Implementation Of Life Skills Curriculum In Secondary Schools In Eldoret East District, Kenya. British Journal of Education, 3(6), 53-70.

[30] Philip Gurney. (2007). Five Factors for Effective Teaching. New Zealand Journal of Teachers' Work, Volume 4, Issue 2, 2007. 